Contract No. and Disclaimer:

This manuscript has been authored by Savannah River Nuclear Solutions, LLC under Contract No. DE-AC09-08SR22470 with the U.S. Department of Energy. The United States Government retains and the publisher, by accepting this article for publication, acknowledges that the United States Government retains a non-exclusive, paid-up, irrevocable, worldwide license to publish or reproduce the published form of this work, or allow others to do so, for United States Government purposes. 


\title{
The Effects of Halide Modifiers on the Sorption Kinetics of the Li-Mg-N-H System
} Christine Price, Joshua Gray, Robert Lascola, Jr., and Donald L Anton*

Savannah River National Laboratory, Aiken, SC, USA

Savannah River National Laboratory

Aiken, SC 29803

* Author to whom correspondence should be addressed; Tel.: +1-803-507-8551; Fax: +1803-652-8137

E-mail address:Donald.Anton@srnl.doe.gov

\begin{abstract}
The effects of different transition metal halides $\left(\mathrm{TiCl}_{3}, \mathrm{VCl}_{3}, \mathrm{ScCl}_{3}\right.$ and $\left.\mathrm{NiCl}_{2}\right)$ on the sorption properties of the 1:1 molar ratio of $\mathrm{LiNH}_{2}$ to $\mathrm{MgH}_{2}$ are investigated. The modified mixtures were found to contain $\mathrm{LiNH}_{2}, \mathrm{MgH}_{2}$ and $\mathrm{LiCl}$. TGA results showed that the hydrogen desorption temperature was reduced with the modifier addition in this order: $\mathrm{TiCl}_{3}>\mathrm{ScCl}_{3}>\mathrm{VCl}_{3}>\mathrm{NiCl}_{2}$. Ammonia release was not significantly reduced resulting in a weight loss greater than the theoretical hydrogen storage capacity of the material. The isothermal sorption kinetics of the modified systems showed little improvement after the first dehydrogenation cycle over the unmodified system but showed drastic improvement in rehydrogenation cycles. X-ray diffraction and Raman spectroscopy identified the cycled material to be composed of $\mathrm{LiH}, \mathrm{MgH}_{2}, \mathrm{Mg}\left(\mathrm{NH}_{2}\right)_{2}$ and $\mathrm{Mg}_{3} \mathrm{~N}_{2}$.
\end{abstract}

Key words: Hydrogen storage; Amides; Metal Hydrides; Kinetics; Raman; XRD 


\section{Introduction}

In a study of more than 300 destabilization reactions using first principle density function theory (DFT), Alapati et al. predicted that the reaction between 1:1 $\mathrm{MgH}_{2}$ and $\mathrm{LiNH}_{2}$ was energetically favorable with an enthalpy of $31.9 \mathrm{~kJ} / \mathrm{molH}_{2}$ [1]. In 2007, Lu et al. showed that the reaction between $\mathrm{MgH}_{2}$ and $\mathrm{LiNH}_{2}$ in a 1:1 molar ratio a new binary light metal nitride, LiMgN, was created for hydrogen storage applications [2]. The initial dehydrogenation reaction pathway was identified as:

$$
\mathrm{LiNH}_{2}+\mathrm{MgH}_{2} \rightarrow \mathrm{LiMgN}+2 \mathrm{H}_{2}
$$

This 1:1 molar ratio of $\mathrm{MgH}_{2}$ to $\mathrm{LiNH}_{2}$ mixture has a theoretical hydrogen storage capacity of $8.2 \mathrm{wt} \%$. The experimental heat of reaction was measured to be $33.5 \mathrm{~kJ} / \mathrm{mol}$ $\mathrm{H}_{2}$ [2], very close to the predicted enthalpy.

Through first-principle calculations of total energies and vibrations free energies, it was suggested that the initial decomposition of 1:1 $\mathrm{LiNH}_{2}: \mathrm{MgH}_{2}$ will proceed as in the following reaction steps [3]:

$$
\begin{gathered}
\mathrm{LiNH}_{2}+\mathrm{MgH}_{2} \rightarrow \mathrm{LiH}+1 / 2 \mathrm{Mg}\left(\mathrm{NH}_{2}\right)_{2}+1 / 2 \mathrm{MgH}_{2} \\
\rightarrow \mathrm{LiH}+1 / 4 \mathrm{Mg}\left(\mathrm{NH}_{2}\right)_{2}+1 / 4 \mathrm{Mg}_{3} \mathrm{~N}_{2}+\mathrm{H}_{2} \\
\rightarrow 1 / 2 \mathrm{LiH}+1 / 4 \mathrm{Mg}_{3} \mathrm{~N}_{2}+1 / 4 \mathrm{Li}_{2} \mathrm{Mg}(\mathrm{NH})_{2}+3 / 2 \mathrm{H}_{2} \\
\rightarrow \mathrm{LiMgN}+2 \mathrm{H}_{2}
\end{gathered}
$$

The first predicted decomposition step would be the exothermic formation of magnesium amide. In the next step, half of the $\mathrm{MgH}_{2}$ and half of the $\mathrm{Mg}\left(\mathrm{NH}_{2}\right)_{2}$ would form $\mathrm{Mg}_{3} \mathrm{~N}_{2}$ through the endothermic reaction, releasing $\mathrm{H}_{2}$ with an enthalpy of $15 \mathrm{~kJ} / \mathrm{mol} \mathrm{H}_{2}$ [3]. The third step is a decomposition reaction which produces a mixed $\mathrm{Li}-\mathrm{Mg}$ imide with an enthalpy of $47 \mathrm{~kJ} / \mathrm{mol} \mathrm{H}_{2}$ [3]. Finally, the ternary nitride is formed with an enthalpy of $80 \mathrm{~kJ} / \mathrm{mol} \mathrm{H}_{2}$ at $227^{\circ} \mathrm{C}$. However, the proposed rehydrogenation and subsequent dehydrogenation process of $\mathrm{LiMgN}$ produces $\mathrm{LiH}, \mathrm{Mg}\left(\mathrm{NH}_{2}\right)_{2}$ and $\mathrm{MgH}_{2}$, as [2]:

$$
\mathrm{LiMgN}+2 \mathrm{H}_{2} \leftrightarrow 1 / 2 \mathrm{Mg}\left(\mathrm{NH}_{2}\right)_{2}+1 / 2 \mathrm{MgH}_{2}+\mathrm{LiH}
$$

Transition metals have been shown to significantly improve kinetics and reduction of dehydrogenation temperatures in many hydrogen storage systems, including $\mathrm{NaAlH}_{4}$ [4-8], $\mathrm{MgH}_{2}$ [9-12], the 1:1 $\mathrm{MgH}_{2}: \mathrm{LiNH}_{2}[2,13]$ and 2:1 $\mathrm{LiNH}_{2}: \mathrm{MgH}_{2}$ [14]. Through the electronic structure and total energy calculation using first principle calculations on the effect of titanium on $\mathrm{MgH}_{2}$, Song et al. found that the bond between magnesium and hydrogen was weakened [15]. Liang et al. investigated the impact of transition metals on hydrogen desorption of $\mathrm{MgH}_{2}$ at $300^{\circ} \mathrm{C}$ and found that the transition metal chemisorbs hydrogen and transfers it to the $\mathrm{Mg}$ matrix creating a nucleation site for the hydride phase [12]. Lu et al. observed an increase in hydrogen absorption kinetics of 1:1 $\mathrm{LiNH}_{2}: \mathrm{MgH}_{2}$ with the addition of $4 \mathrm{wt} \% \mathrm{TiCl}_{3}$ resulting in an increase in capacity from $5 \mathrm{wt} \%$ to $7.9 \mathrm{wt} \%$ [2]. For the $2: 1 \mathrm{LiNH}_{2}: \mathrm{MgH}_{2}$ system, through density of states analysis, Wang et al. found that the $\mathrm{N}-\mathrm{H}$ bonds were weakened by a Ti atom substituted by a $\mathrm{Li}$ atom and the decreased energy value of $\mathrm{Li}$ vacancy formation indicated improvement in rehydrogenation of $\mathrm{Li}_{2} \mathrm{MgN}_{2} \mathrm{H}_{2}$ with Ti additive [14].

One issue related to the application of metal-N-H storage systems is ammonia formation that takes place simultaneously with $\mathrm{H}_{2}$ release $[16,17]$. Through the use of Draeger tubes on the 2:1 $\mathrm{LiNH}_{2}: \mathrm{MgH}_{2}$ system, Luo et al. showed that ammonia concentration was strongly dependent on the desorption temperature with concentrations 
of $180 \mathrm{ppm}$ measured at $180^{\circ} \mathrm{C}$ and $720 \mathrm{ppm}$ at $240^{\circ} \mathrm{C}$ [17]. In a separate analysis, the effect of milling duration on ammonia release from the 2:1 mixture during heating was investigated, resulting in over $30 \mathrm{ppm} / \mathrm{mg}$ for unmilled samples and under $10 \mathrm{ppm} / \mathrm{mg}$ for samples milled for 180 minutes using high-energy milling [18]. In a separate study on the effect of the variation of $\mathrm{LiH}$ composition in the $\mathrm{Mg}\left(\mathrm{NH}_{2}\right)_{2}-\mathrm{LiH}$ mixture, Hu et al. observed that if the molar ratio of $\mathrm{LiH}$ was below 2, ammonia evolution occurred during dehydrogenation reactions and if the molar ratio was above 2 a reduction in hydrogen storage efficiency was observed [19]. During hydrogen sorption of the 2:1 $\mathrm{LiH}: \mathrm{Mg}\left(\mathrm{NH}_{2}\right)_{2}$ mixture, they observed a ternary imide with the composition of $\mathrm{Li}_{2} \mathrm{Mg}_{2}(\mathrm{NH})_{3}$ as an intermediate $[19,20]$.

In this present article, we report the effects of different metal halide additions on the ammonia release and isothermal sorption kinetics of the $1: 1 \mathrm{LiNH}_{2}: \mathrm{MgH}_{2}$ system. The influence of these halides has been investigated using thermogravimetric analysis (TGA), isothermal kinetics, x-ray diffraction (XRD) and Raman spectroscopy.

\section{Experimental Procedures}

The starting materials, lithium amide ( $\mathrm{LiNH}_{2}, 95 \%$ purity, Aldrich), magnesium hydride $\left(\mathrm{MgH}_{2},>97 \%\right.$ purity, Gelest Inc), titanium chloride $\left(\mathrm{TiCl}_{3}, 99 \%\right.$, Aldrich), nickel chloride $\left(\mathrm{NiCl}_{2}, 99 \%\right.$, Aldrich), scandium chloride $\left(\mathrm{ScCl}_{3}, 99 \%\right.$, Aldrich) and vanadium chloride $\left(\mathrm{VCl}_{3}, 99 \%\right.$, Aldrich) were purchased and used without alteration. Mixtures of $\mathrm{LiNH}_{2}$ and $\mathrm{MgH}_{2}$ with and without $1.5 \mathrm{~mol} \%$ of the transition metal halides were prepared using Fritsch planetary milling technique. Three grams of mixtures were loaded into the milling jars in the argon glove box while maintaining a 30:1 ball to sample weight ratio. The powders were milled for 2 hours with 30 minute cycles at $500 \mathrm{rpm}$.

Desorption properties were monitored as a function of temperature and time using a thermogravimetric analyzer (TGA) coupled with a residual gas analyzer (RGA). The TGA was located inside an argon glove box to prevent the samples from oxidizing. Eight milligram samples were loaded into a stainless steel microbalance pan and heated from $30^{\circ} \mathrm{C}$ to $400^{\circ} \mathrm{C}$ with a heating rate of $5^{\circ} \mathrm{C} / \mathrm{min}$ under a constant flow of argon gas. The effluent gases from the TGA were constantly monitored for $\mathrm{H}_{2}, \mathrm{NH}_{3}, \mathrm{H}_{2} \mathrm{O}$ and $\mathrm{O}_{2}$ using a Hiden Analytical residual gas analyzer (RGA).

Hydrogen desorption and absorption kinetics measurements were carried out using a Sievert's apparatus (PCTPro-2000, Setaram). Approximate 0.5 gram samples were loaded into a stainless steel reactor vial and sealed in a glovebox. Standard isothermal discharge procedure called for heating of the sample under 110 bar or greater, in order to prevent premature hydrogen release to occur while heating. Once the desired discharge temperature was reached, the sample was discharged into the largest reservoir, $1170 \mathrm{~mL}$, into a backpressure of 1 bar. During subsequent recharging cycles, the sample was heated to $180^{\circ} \mathrm{C}$ under active vacuum and then exposed to $100 \mathrm{bar}$ of $\mathrm{H}_{2}$ pressure. During the dehydrogenation and hydrogenation cycles, the sample temperature and reservoir pressure were recorded. The amount of $\mathrm{H}_{2}$ discharge and uptake was determined from the changes in pressure within the calibrated volume reservoirs. A 
blank reactor vial was run under standard discharge conditions to identify the effects of gas thermal expansion during heating and volume expansion.

Powder x-ray diffraction (XRD) patterns of the as-milled, dehydrogenated and rehydrogenated materials were collected using a Rigaku Dmax/2100 ( $\mathrm{Cu} \mathrm{K}_{\alpha}$ radiation). The samples were mounted on a glass slide and covered with Kapton ${ }^{\circledR}$ film while under argon. The XRD patterns were recorded at $2 \theta$ spanning 5 to $80^{\circ}$ with a scanning rate of $0.02 \% \mathrm{~min}$.

Raman spectra were obtained with $532 \mathrm{~nm}$ excitation (Verdi-2W, Coherent, Inc.) in the backscattering mode, using an imaging probe (MultiRxn Probe, Kaiser Optical Systems) with a $5 \mathrm{~mm}$ working distance. Excitation powers were restricted to less than $20 \mathrm{~mW}$ at the sample, in a spot approximately $200 \mu \mathrm{m}$ in diameter, to avoid sample degradation. No sample changes were visible after irradiation under these conditions. Scattered light was detected with a holographic spectrometer (Holospec VPH, Kaiser Optical Systems) and CCD camera (DV420A, Andor) electrically cooled to $-55^{\circ} \mathrm{C}$. Spectral resolution is 4-6 $\mathrm{cm}^{-1}$, with a shift accuracy of $\pm 1 \mathrm{~cm}^{-1}$. Spectra were measured at room temperature (approximately $20^{\circ} \mathrm{C}$ ). Samples were contained in a sealed quartz vial; contributions of the vial to the spectra were subtracted. These samples exhibited a large background signal, probably due to scattering by metallic $\mathrm{Mg}$ (present in the $\mathrm{MgH}_{2}$ source) and/or $\mathrm{Ti}$ (from $\mathrm{TiCl}_{3}$ in the modified samples). The background was simulated by fitting to a polynomial and then subtracted. Despite this step, some of the weaker Raman bands presumed to be present (e.g. for $\mathrm{MgH}_{2}$ ) could not be recovered.

\section{Results and Discussion}

\subsection{Characterization of As-milled Systems}

Figure 1 compares the XRD patterns of the unmodified, $\mathrm{TiCl}_{3}$ and $\mathrm{ScCl}_{3}$ modified mixtures after milling. Identification of $\mathrm{LiCl}$ peaks, shows clearly that the halide addition promoted initial decomposition of $\mathrm{LiNH}_{2}$. This was a typical observation for all the 1:1 $\mathrm{LiNH}_{2}: \mathrm{MgH}_{2}$ mixtures with transition metal halide modifiers. Furthermore, the unmodified mixture showed no indication of such a decomposition, which is in agreement with the results from Liu et al., who observed the absence of gas evolution for milling times under 12 hours at $500 \mathrm{rpm}$ [21]. 
$* \mathrm{MgH}_{2} \square \mathrm{LiNH}_{2} \circ \mathrm{LiCl}$
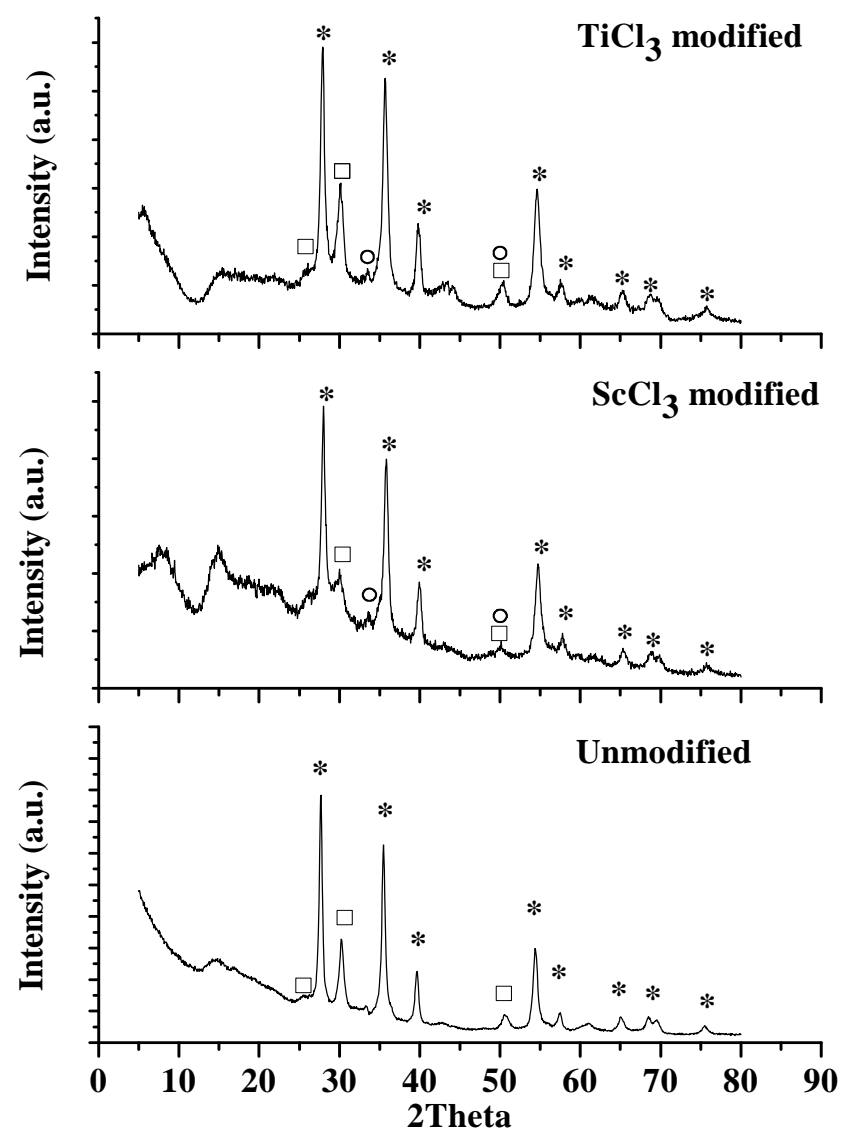

Figure 1. XRD analysis of unmodified (bottom), $\mathrm{ScCl}_{3}$ (middle) and $\mathrm{TiCl}_{3}$ (top) modified 1:1 $\mathrm{LiNH}_{2}: \mathrm{MgH}_{2}$ after 2 hours of Fritsch milling at 500rpm.

\subsection{Decomposition of the modified and unmodified systems}

The TGA curves of the unmodified and modified materials show that the weight loss of the modified mixture starts at lower temperatures than the unmodified, as seen in Figure 2. The slight increase in weight percent observed at the beginning of the TGA curves are attributed to a buoyancy effect as the carrier gas is heated. 


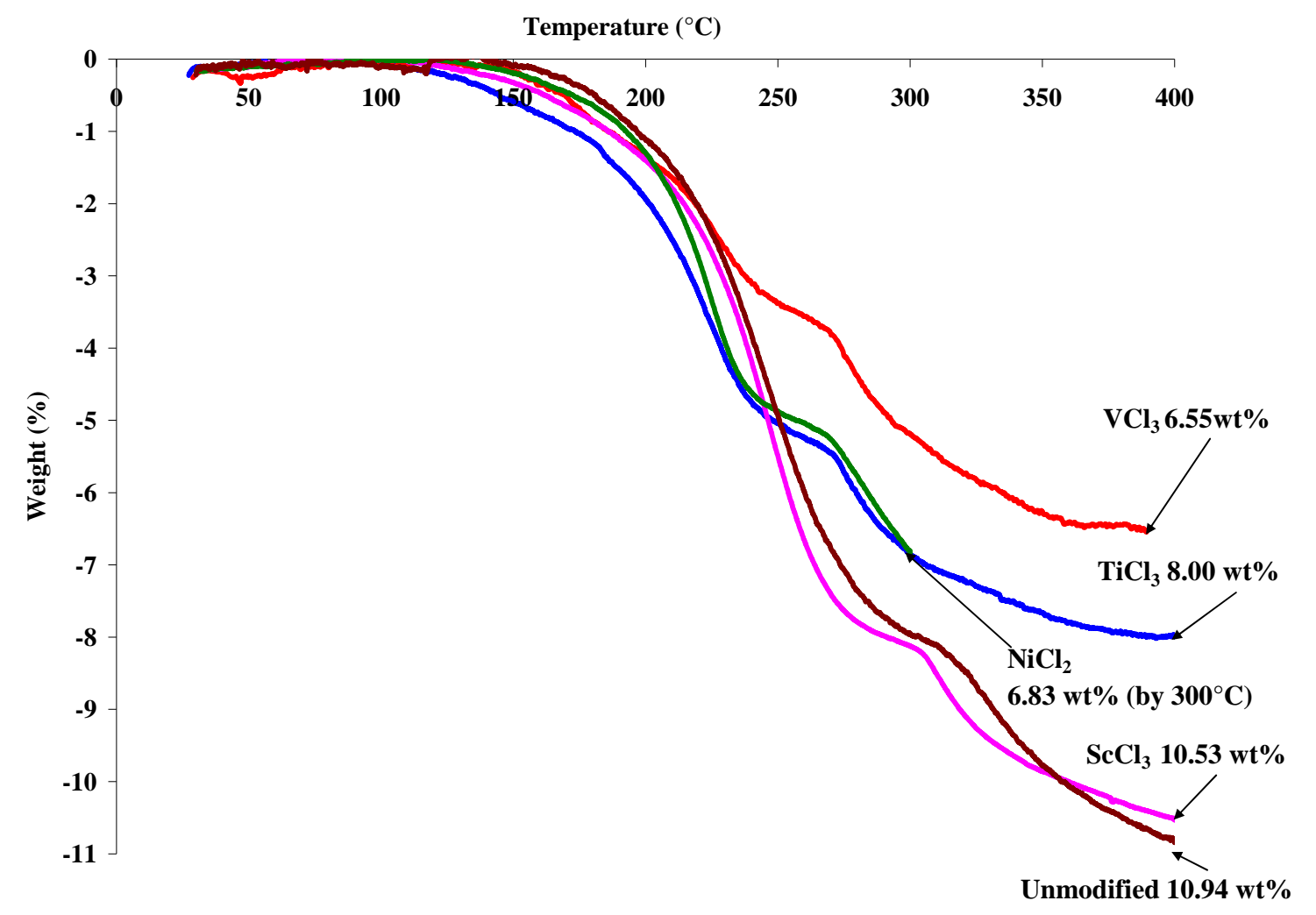

Figure 2. TGA analysis of the decomposition of unmodified and modified $1: 1 \mathrm{LiNH}_{2}: \mathrm{MgH}_{2}$ mixture at a heating rate of $5^{\circ} \mathrm{C} / \mathrm{min}$.

By determining the derivative of weight change with time over a given time period, the initial hydrogen desorption temperature of the unmodified mixture was determined to be in the range of 135 to $145^{\circ} \mathrm{C}$, which is slightly higher than the initial desorption temperature observed by Lu et al. of $120^{\circ} \mathrm{C}$ for samples synthesized using jar roll milling for 24 hours [2]. The ability of the metal halides to reduce the initial temperature of desorption follows the order: $\mathrm{TiCl}_{3}>\mathrm{ScCl}_{3}>\mathrm{VCl}_{3}>\mathrm{NiCl}_{2}$. The approximate ranges for the modified samples are listed in Table 1.

The RGA results of hydrogen gas composition during the TGA experiments are given in Figure 3. This data show the unmodified material decomposition is comprised of three hydrogen releases steps. With the initial hydrogen release starting between 135 and $145^{\circ} \mathrm{C}$ and peaking at approximately $205^{\circ} \mathrm{C}$, the sample lost $1 \mathrm{wt} \%$. The second hydrogen release peaked at $260^{\circ} \mathrm{C}$. During this time, a total of $6.48 \mathrm{wt} \%$ was lost. It was during this step that $\mathrm{NH}_{3}$ also peaked at $265^{\circ} \mathrm{C}$, as illustrated in Figure 4. A similar ammonia emission temperature was observed by Liang, et al. for a 1:1 $\mathrm{LiNH}_{2}: \mathrm{MgH}_{2}$ milled for 2 hours [22]. The third hydrogen release peaked at $340^{\circ} \mathrm{C}$. The unmodified mixture lost a total of $10.94 \mathrm{wt} \%$ during decomposition, which is significantly higher than the theoretical hydrogen capacity of $8.14 \mathrm{wt} \%$. This increase is attributed to release of ammonia from the decomposition of unreacted $\mathrm{LiNH}_{2}$ and the slow reaction kinetics between $\mathrm{MgH}_{2}$ and $\mathrm{NH}_{3}[17,18]$.

The total weight lost by the $1: 1 \mathrm{LiNH}_{2}: \mathrm{MgH}_{2}$ mixture with $1.5 \mathrm{~mol}^{\circ} \mathrm{TiCl}_{3}$ is $8.00 \mathrm{wt} \%$, which is slightly higher than the theoretical hydrogen capacity of $7.85 \mathrm{wt} \%$. 
From Table 1, the range of initial hydrogen release is between 90 and $100^{\circ} \mathrm{C}$, which is a significant reduction in temperature from the unmodified mixture. The other hydrogen releases were also shifted to lower temperatures indicating that the $\mathrm{TiCl}_{3}$ promoted the dehydrogenation reaction, as depicted in Figure 3. Ammonia release peaked at approximately $245^{\circ} \mathrm{C}$, as illustrated Figure 4 , which is a $20^{\circ} \mathrm{C}$ reduction from the unmodified The sample containing $\mathrm{VCl}_{3}$, where initial $\mathrm{H}_{2}$ release occurred between 110 and $120^{\circ} \mathrm{C}$, showed very similar reduction in peak hydrogen and ammonia release temperatures. However, as seen in Table 1, the measured weight loss was significantly lower than the theoretical capacity indicating possible hydrogen release during milling.

The addition of $\mathrm{ScCl}_{3}$ significantly impacted the 1:1 $\mathrm{LiNH}_{2}: \mathrm{MgH}_{2}$ mixture, resulting in the largest weight loss of the modified samples with $10.53 \mathrm{wt} \%$, which is nearly $40 \%$ larger than its theoretical $\mathrm{H}_{2}$ capacity of $7.48 \%$. It also resulted in only 2 peak hydrogen releases, as shown in Figure 3. The first hydrogen release peaked at $270^{\circ} \mathrm{C}$ with a total of $8.3 \mathrm{wt} \%$ lost, which included both $\mathrm{H}_{2}$ and $\mathrm{NH}_{3}$ emission. The peak ammonia release temperature was at approximately $280^{\circ} \mathrm{C}$, which is a $15^{\circ} \mathrm{C}$ increase from the unmodified sample. The second peak hydrogen release was at approximately $335^{\circ} \mathrm{C}$ where the remaining weight loss was attributed to hydrogen release.

From the addition of transition metal halides, the initial hydrogen desorption temperature of the 1:1 $\mathrm{LiNH}_{2}: \mathrm{MgH}_{2}$ system was reduced. As seen in Table 1, the initial hydrogen desorption for the modified systems began between $90^{\circ} \mathrm{C}$ and $120^{\circ} \mathrm{C}$, which is lower than the release temperature of $135^{\circ} \mathrm{C}$ for the unmodified material, with $\mathrm{TiCl}_{3}$ and $\mathrm{ScCl}_{3}$ having the largest effect on temperature reduction. From literature, scandium has been shown to dissociate the $\mathrm{Mg}-\mathrm{H}$ bonds since $\mathrm{Sc}$ has the lowest $3 \mathrm{~d}$ orbital occupancy among the $3 \mathrm{~d}$ transition metals which largely contributes to the donation of the electrons from the bonding orbitals to $\mathrm{MgH}_{2}$ [23] This suggests that Ti and Sc are more effective at allowing the conversion of $\mathrm{LiNH}_{2}$ and $\mathrm{MgH}_{2}$ to $\mathrm{LiH}, \mathrm{Mg}\left(\mathrm{NH}_{2}\right)_{2}$ and $\mathrm{H}_{2}$ to occur at a lower temperature by weakening the $\mathrm{Mg}-\mathrm{H}$ bond. However, it is important to note that the $\mathrm{NiCl}_{2}$ modified sample showed the largest hydrogen release prior to $300^{\circ} \mathrm{C}$, which peaked at $275^{\circ} \mathrm{C}$. This is also similar to the results reported by Tsuda et al., who showed that the high $3 \mathrm{~d}$ orbital occupancy of $\mathrm{Ni}$ contributes to the back-donation of the electrons to the antibonding orbitals of $\mathrm{MgH}_{2}$ allowing for easier $\mathrm{Mg}-\mathrm{H}$ dissociation [23].

Additive compositions also greatly effected ammonia release. As seen in Figure 4, the mixtures with $\mathrm{TiCl}_{3}$ and $\mathrm{VCl}_{3}$ released ammonia at temperatures lower than the unmodified material, while the mixtures modified with $\mathrm{ScCl}_{3}$ and $\mathrm{NiCl}_{2}$ increased the temperature. As seen by the XRD pattern for the $\mathrm{TiCl}_{3}$ and $\mathrm{ScCl}_{3}$ samples, in Error! Reference source not found., $\mathrm{LiCl}$ formed during milling via a metathesis reaction between $\mathrm{LiNH}_{2}$ and the halide. It is possible that during decomposition, the metathesis reaction was promoted, resulting in the further formation of $\mathrm{LiCl}$ and release of $\mathrm{NH}_{3}$. Also, as stated by Liang et al., ammonia release could be the result from thermal selfdecomposition of $\mathrm{LiNH}_{2}$ due to its large particle size and uneven mixing with $\mathrm{MgH}_{2}$ cause by the short milling time [22]. 


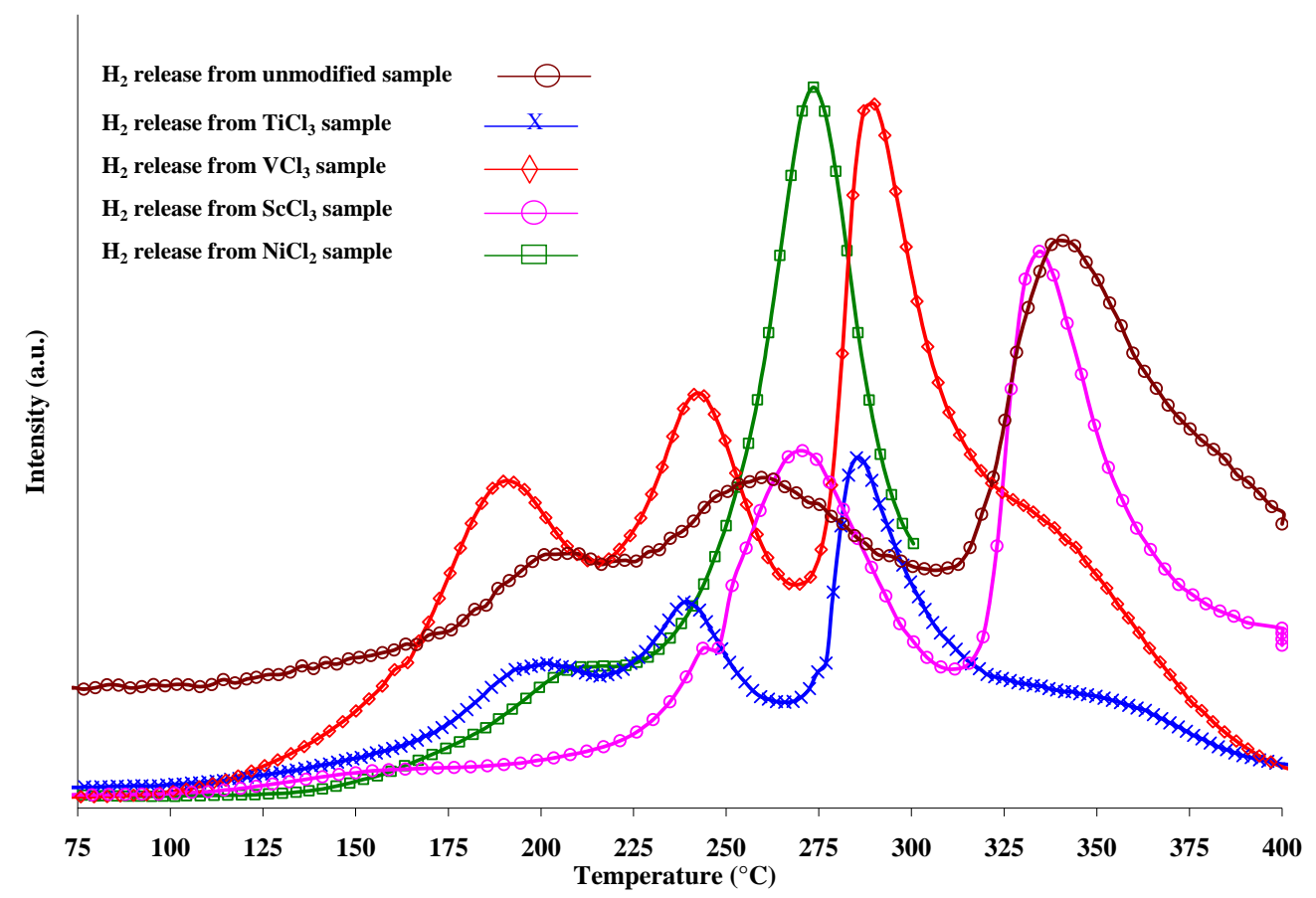

Figure 3. RGA curves of the hydrogen (Mass 2) release for the unmodified and modified 1:1 $\mathrm{LiNH}_{2}: \mathrm{MgH}_{2}$ mixtures after milling for 2 hours.

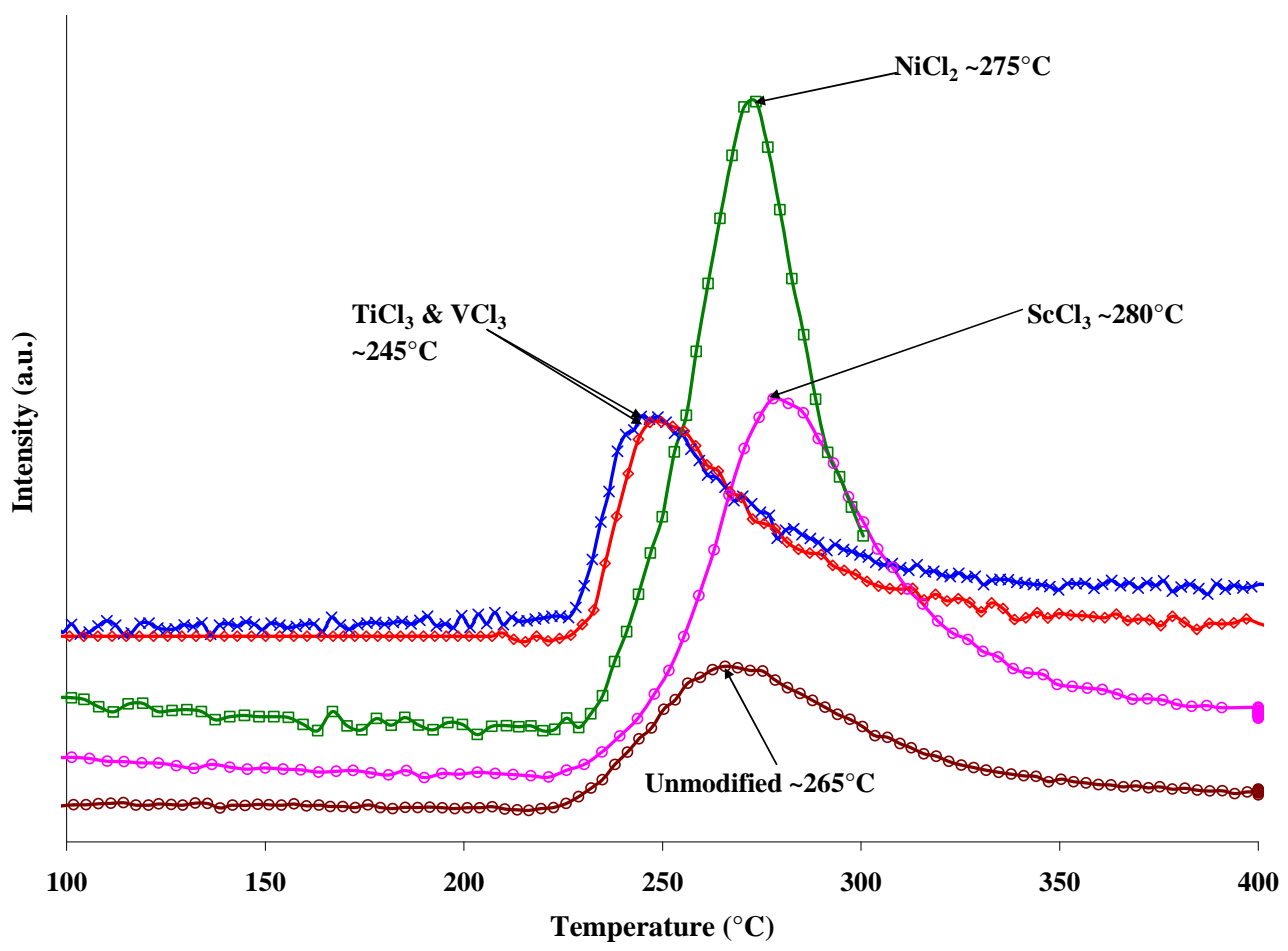

Figure 4. RGA curves of the ammonia release for the unmodified and modified 1:1 $\mathrm{LiNH}_{2}: \mathrm{MgH}_{2}$ mixtures after milling for 2 hours. 
Table 1. Summary of TGA/RGA decomposition data of the as-milled 1:1 $\mathrm{LiNH}_{2}: \mathrm{MgH}_{2}$ samples with and without various modifiers while heating from RT to $400^{\circ} \mathrm{C}$ at $5^{\circ} \mathrm{C} / \mathrm{min}$.

\begin{tabular}{|c|c|c|c|c|c|c|c|}
\hline Modification & $\begin{array}{c}\text { Theoretical } \\
\mathbf{H}_{2} \\
\text { Wt \% }\end{array}$ & $\begin{array}{c}\text { Total Wt } \\
\% \\
\text { Released }\end{array}$ & $\begin{array}{l}\text { Initial Onset } \\
\text { Temperature } \\
\qquad\left({ }^{\circ} \mathrm{C}\right)\end{array}$ & $\begin{array}{c}\mathbf{H}^{\mathbf{1}} \\
\left({ }^{\circ} \mathrm{C}\right)\end{array}$ & $\begin{array}{c}\mathbf{H}^{2} \\
\left({ }^{\circ} \mathrm{C}\right)\end{array}$ & $\begin{array}{c}\mathbf{H}^{3} \\
\left({ }^{\circ} \mathrm{C}\right)\end{array}$ & $\begin{array}{c}{\text { Peak } \mathrm{NH}_{3}} \text { Release } \\
\text { Temperature } \\
\left({ }^{\circ} \mathrm{C}\right) \\
\end{array}$ \\
\hline Unmodified & 8.14 & 10.94 & $135-145$ & 205 & 260 & 340 & 260 \\
\hline $\begin{array}{l}1.5 \mathrm{~mol}^{2} \% \\
\mathrm{TiCl}_{3}\end{array}$ & 7.85 & 8.00 & $90-100$ & 200 & 240 & 285 & 245 \\
\hline $\begin{array}{l}1.5 \mathrm{~mol}^{2} \% \\
\mathrm{VCl}_{3}\end{array}$ & 7.46 & 6.55 & $110-120$ & 190 & 240 & 290 & 245 \\
\hline $\begin{array}{l}1.5 \mathrm{~mol}^{\circ} \% \\
\mathrm{ScCl}_{3}\end{array}$ & 7.48 & 10.53 & $110-115$ & - & 270 & 335 & 280 \\
\hline $\begin{array}{l}1.5 \mathrm{~mol}^{\circ} \% \\
\mathrm{NiCl}_{2} \\
\left(\text { by } 300^{\circ} \mathrm{C}\right)\end{array}$ & 7.57 & 6.83 & $120-130$ & 210 & 275 & - & 270 \\
\hline
\end{tabular}

\subsubsection{Effect of Modifiers on Isothermal Sorption Kinetics}

The impact of the modifiers on the kinetic performance during the isothermal sorption of 1:1 $\mathrm{LiNH}_{2}: \mathrm{MgH}_{2}$ was also investigated. The overall sorption rate during the first 30 minutes ( 0.5 hours) of the first and fourth dehydrogenation cycles are shown in Figure 5. The sharp change in slope observed during the first desorption cycle indicates a change in reaction mechanisms and kinetics.

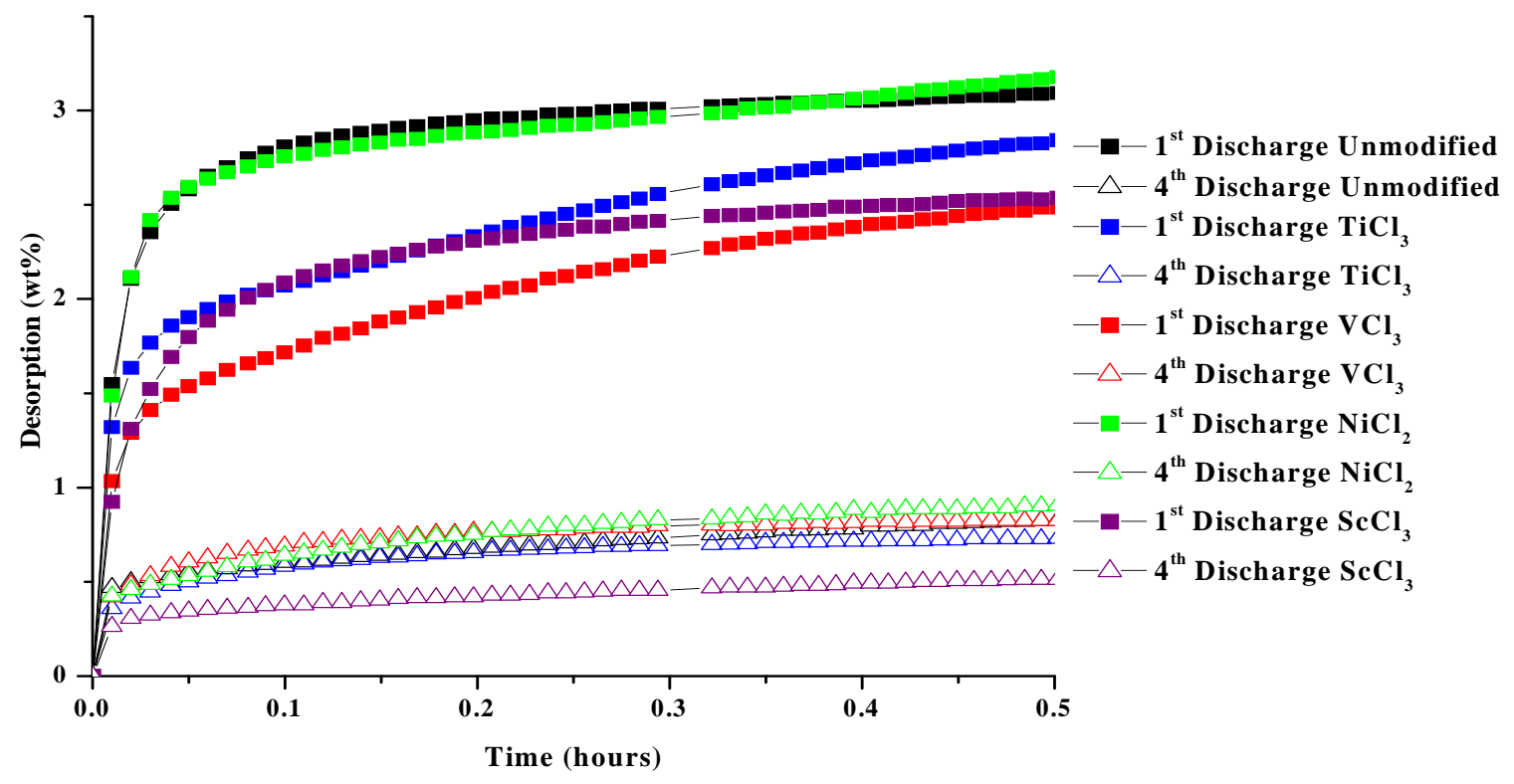

Figure 5. First (solid) and fourth (hollow) isothermal desorption curves at $260^{\circ} \mathrm{C}$ into 1 bar for the (black) unmodified and samples containing $1.5 \mathrm{~mol} \%$ (blue) $\mathrm{TiCl}_{3}$, (red) $\mathrm{VCl}_{3}$, (green) $\mathrm{NiCl}_{2}$ and (purple) $\mathrm{ScCl}_{3}$ modifiers. 
During the fourth desorption cycle, illustrated in Figure 5, a significant reduction in kinetics is observed for all samples. The addition of the modifiers lowered the initial desorption temperature but they did not enhance the kinetics of the isothermal desorption reaction past the first cycle, which is similar to the results observed by Lohstroh et al. for $\mathrm{TiCl}_{3}$ with the 2:1 $\mathrm{LiNH}_{2}: \mathrm{MgH}_{2}$ [24]. Over four cycles, the samples desorbed $2.0 \mathrm{wt} \%$, this is significantly lower than the theoretical hydrogen capacity for the system. Possible barriers preventing full capacity sorption are discussed below.

After each desorption cycles, vacuum was applied to the sample for 30 minutes while it cooled from $260^{\circ} \mathrm{C}$ to $180^{\circ} \mathrm{C}$, providing a fully desorbed sample. During the absorption cycles at $180^{\circ} \mathrm{C}$, the samples recharged between 4 and $6 \mathrm{wt} \%$, with the $\mathrm{ScCl}_{3}$ and $\mathrm{NiCl}_{2}$ modified sample having the highest absorption capacity followed by the unmodified, $\mathrm{VCl}_{3}$ and $\mathrm{TiCl}_{3}$ samples respectively.
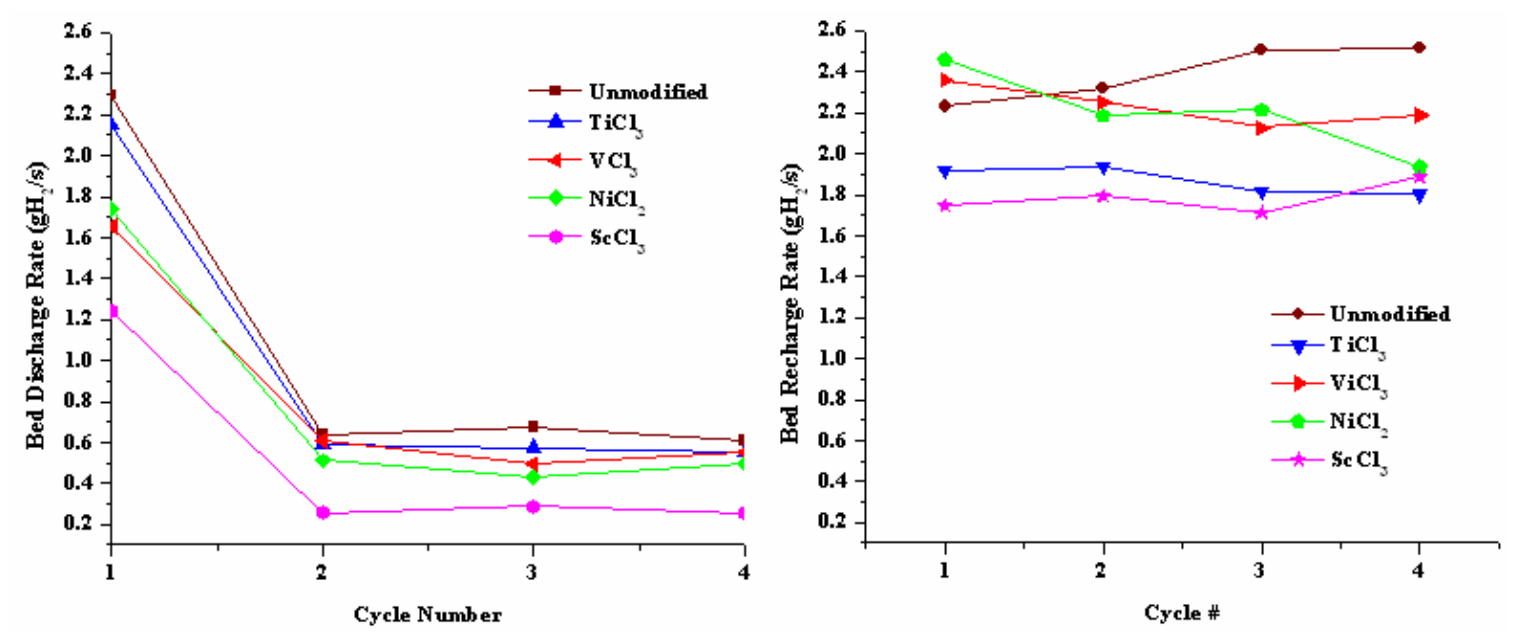

Figure 6. Overall bed discharge (A) and recharge (B) rates determined from isothermal dehydrogenation cycle at $260^{\circ} \mathrm{C}$ into 1 bar of back pressure and rehydrogenation cycle at $180^{\circ} \mathrm{C}$ under 100 bar hydrogen.

In order to compare the rates of charge and discharge to the DOE 2010 technical targets, the average sorption rate in grams of hydrogen per second per gram of media during the first 30 minutes of cycling was determined and reported here as $\left[\mathrm{gH}_{2} / \mathrm{s}\right] / \mathrm{kg}_{\text {material. }}$. This rate was then converted to bed discharge/charge rate using the estimated bed size, to hold $5 \mathrm{~kg}$ of $\mathrm{H}_{2}$. The US DOE has set the goal of minimum charging rates of $20 \mathrm{~g} / \mathrm{sec}$. and discharging rates of $5 \mathrm{~g} / \mathrm{sec}$. for a $5 \mathrm{~kg}$ capacity storage system [25]. The current rates of sorption are significantly below these goals, as seen in Figure 6. One possible cause for low sorption rates is the possible loss of nitrogen through $\mathrm{NH}_{3}$ emission and the formation of magnesium nitride, $\mathrm{Mg}_{3} \mathrm{~N}_{2}$, which is the predominate product seen from XRD in Figure 7(A). Another cause could be the agglomeration of particle due to the high discharge temperature, as seen from the increase in average $\mathrm{MgH}_{2}$ from $35 \mathrm{~nm}$ (as-milled) to $50 \mathrm{~nm}$ after cycling. Achievement of enhanced kinetics with minimal effect to capacity will be required to warrant further development and implementation of these materials. 


\subsubsection{Phase Identification}

XRD analysis was performed after the second discharged at $260^{\circ} \mathrm{C}$ and the fourth rehydrogenation cycle at $180^{\circ} \mathrm{C}$ on the unmodified 1:1 $\mathrm{LiNH}_{2}: \mathrm{MgH}_{2}$. The XRD spectrum for the dehydrogenated sample shown Figure 7 in identifies cubic $\mathrm{LiMgN}$ and $\mathrm{Mg}_{3} \mathrm{~N}_{2}$, similar to the results observed by Lu et al. $[2,13]$.
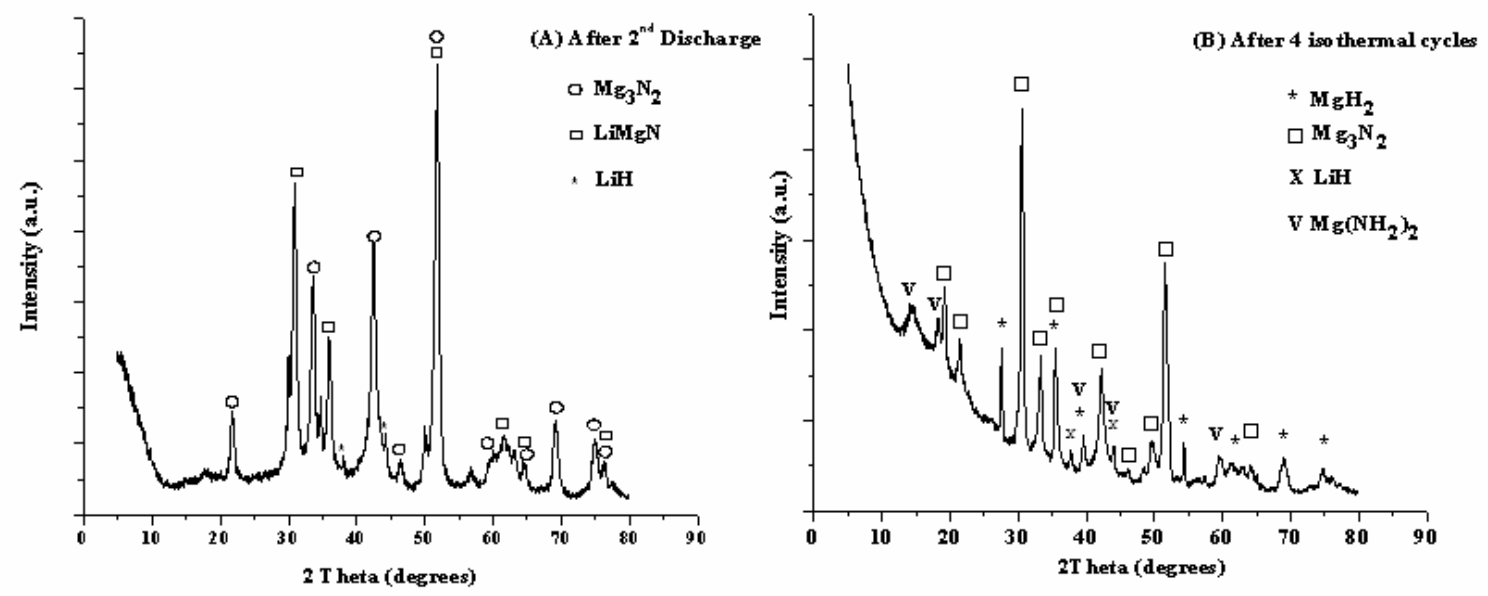

Figure 7. XRD pattern of 1:1 $\mathrm{LiNH}_{2}: \mathrm{MgH}_{2}$ without modifications (A) after $2^{\text {nd }}$ desorption and (B) $4^{\text {th }}$ absorption. The diffraction pattern of the dehydrogenated product is similar to that of cubic LiMgN identified by Lu et al. $[2,13]$ and $\mathrm{Mg}_{3} \mathrm{~N}_{2}$ while the predominate components of the absorption pattern include $\mathrm{MgH}_{2}, \mathrm{LiH}, \mathrm{Mg}\left(\mathrm{NH}_{2}\right)_{2}$ and $\mathrm{Mg}_{3} \mathrm{~N}_{2}$.

However, the $\mathrm{Li}_{2} \mathrm{Mg}_{2}(\mathrm{NH})_{3}$ observed by Osborn et al. after dehydrogenation at $210^{\circ} \mathrm{C}[25]$ was not observed. The XRD pattern of the hydrogenated sample after the $4^{\text {th }}$ absorption cycle in Figure 7(B) shows that after the fourth rehydrogenation $\mathrm{Mg}_{3} \mathrm{~N}_{2}$, $\mathrm{MgH}_{2}, \mathrm{LiH}$ and $\mathrm{Mg}\left(\mathrm{NH}_{2}\right)_{2}$ are the dominant products. Here again, the $\mathrm{Li}_{2} \mathrm{Mg}_{2}(\mathrm{NH})_{3}$ phase seen by Lui et al. [21] in their rehydrogenated sample was not observed in the XRD pattern. The discrepancies with the reported literature were attributed different sample preparation techniques and cycling conditions. 


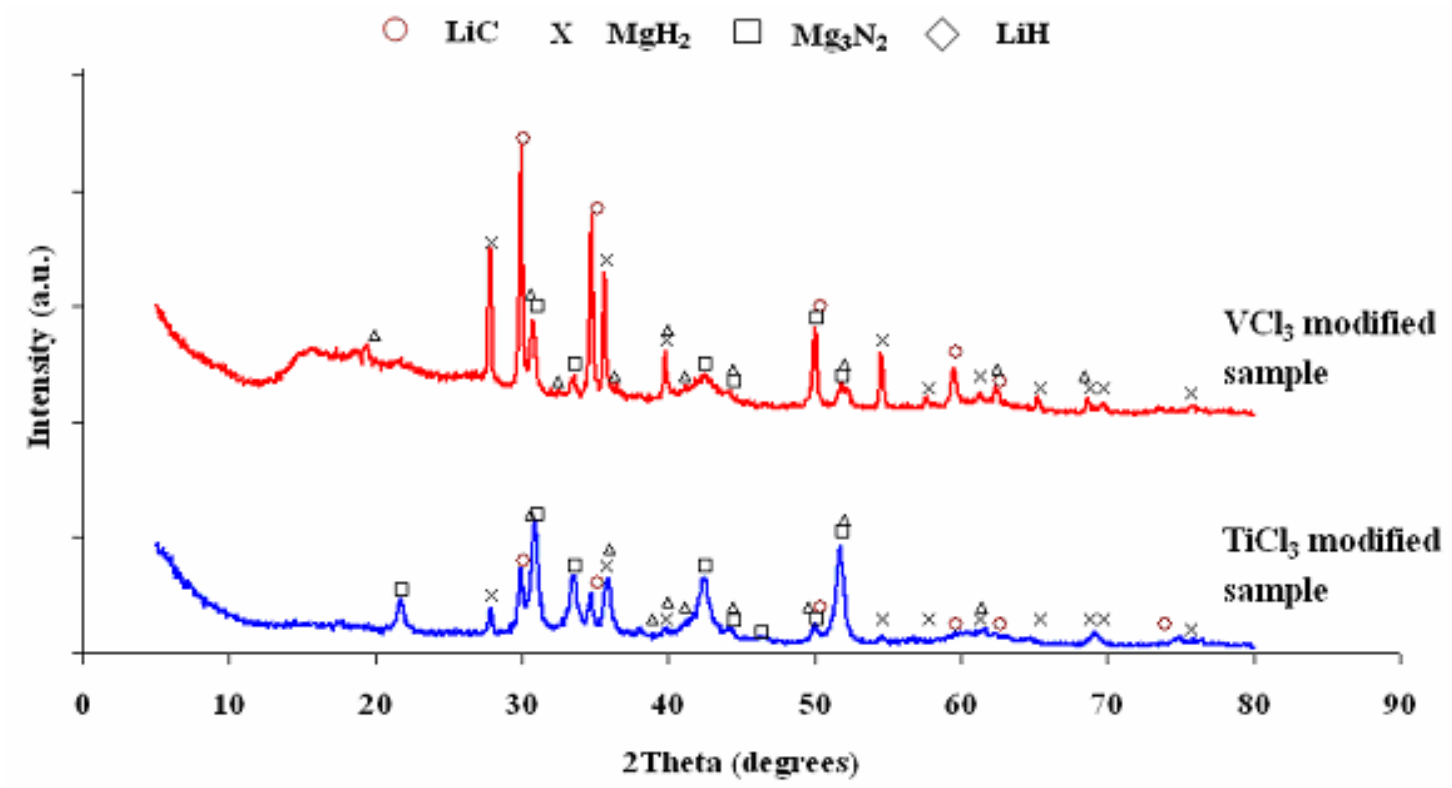

Figure 8. The XRD spectra after the $1^{\text {st }}$ complete cycle of $1: 1 \mathrm{LiNH}_{2}: \mathrm{MgH}_{2}$ modified with $1.5 \mathrm{~mol} \% \mathrm{TiCl}_{3}$ or $\mathrm{VCl}_{3}$ showing the predominant recharged species to be $\mathrm{MgH}_{2}, \mathrm{LiH}$, and $\mathrm{Mg}_{3} \mathrm{~N}_{2}$. Since the sample was not annealed before x-ray examination, $\mathrm{Mg}\left(\mathrm{NH}_{2}\right)_{2}$ peaks were not clearly identified. The peaks associated with $\mathrm{LiCl}$ are indicative of the metathesis reaction between $\mathrm{LiNH}_{2}$ and the transition metal chlorides.

The XRD spectra after one complete isothermal cycle given in Figure 8 further illustrates the formation of salts, predominately $\mathrm{LiCl}$ as a result of cycling. The metathesis reaction results in the loss of essential nitrogen due to ammonia release, as possibly:

$$
(x+1) \mathrm{LiNH}_{2}+\mathrm{TmCl}_{x} \rightarrow x \mathrm{LiCl}+\mathrm{Tm}^{\circ}+x \mathrm{NH}_{3}
$$

thus preventing the reversible reaction from occurring. This metathesis reaction has been observed during the dry ball milling process of $\mathrm{NaAlH}_{4}$ with $\mathrm{TiCl}_{3}$, resulting in the reduction of $\mathrm{TiCl}_{3}$ by the $\mathrm{Na}$ to form $\mathrm{NaCl}$ and metallic $\mathrm{Ti}$ [26]. Sandrock et al. went on to show that increasing the $\mathrm{TiCl}_{3}$ loading resulted in an elimination of $\mathrm{H}$-capacity with the formation of $\mathrm{NaCl}, \mathrm{Al}$ and $\mathrm{Ti}$, all of which do not store hydrogen [26].

To further identify the as-milled, dehydrogenated and hydrogenated phases, Raman spectroscopy was performed on the system modified with $\mathrm{TiCl}_{3}$, with the results shown in Figure 9 (A) and (B). Raman spectra of the as-milled indicates the presence of unreacted $\mathrm{LiNH}_{2}$ after milling. The vibrational bands observed at $3262 \mathrm{~cm}^{-1}(\mathrm{~N}-\mathrm{H}$ symmetric stretch) and $3323 \mathrm{~cm}^{-1}$ (unresolved N-H asymmetric stretch doublet) match literature spectra of the pure material $[11,23]$. Weak low-frequency $\left(<500 \mathrm{~cm}^{-1}\right)$ bands associated with lattice translational and librational modes are not visible, most likely due to low measurement sensitivity against a large scattering background. A very weak peak observed at $\sim 950 \mathrm{~cm}^{-1}$ is consistent with the expected $\mathrm{MgH}_{2}$ vibration at $954 \mathrm{~cm}^{-1}$ [27], but is not definitive. However, no other peaks appear in this region of the spectrum that would suggest the presence of other reaction products.

The desorbed sample was taken after the second discharge cycle and the rehydrogenated sample was taken after the fourth recharge cycle. As expected for the dehydrided sample, there is little or no Raman activity observable in the H-N-H stretching regions. The low-frequency region shows the growth of a clear doublet at 379 
(strong) $\mathrm{cm}^{-1}$ and 341 (weak) $\mathrm{cm}^{-1}$. These peaks are not coincident with the reported spectrum for LiMgN in which a single broad peak is observed at $492 \mathrm{~cm}^{-1}$ [28].
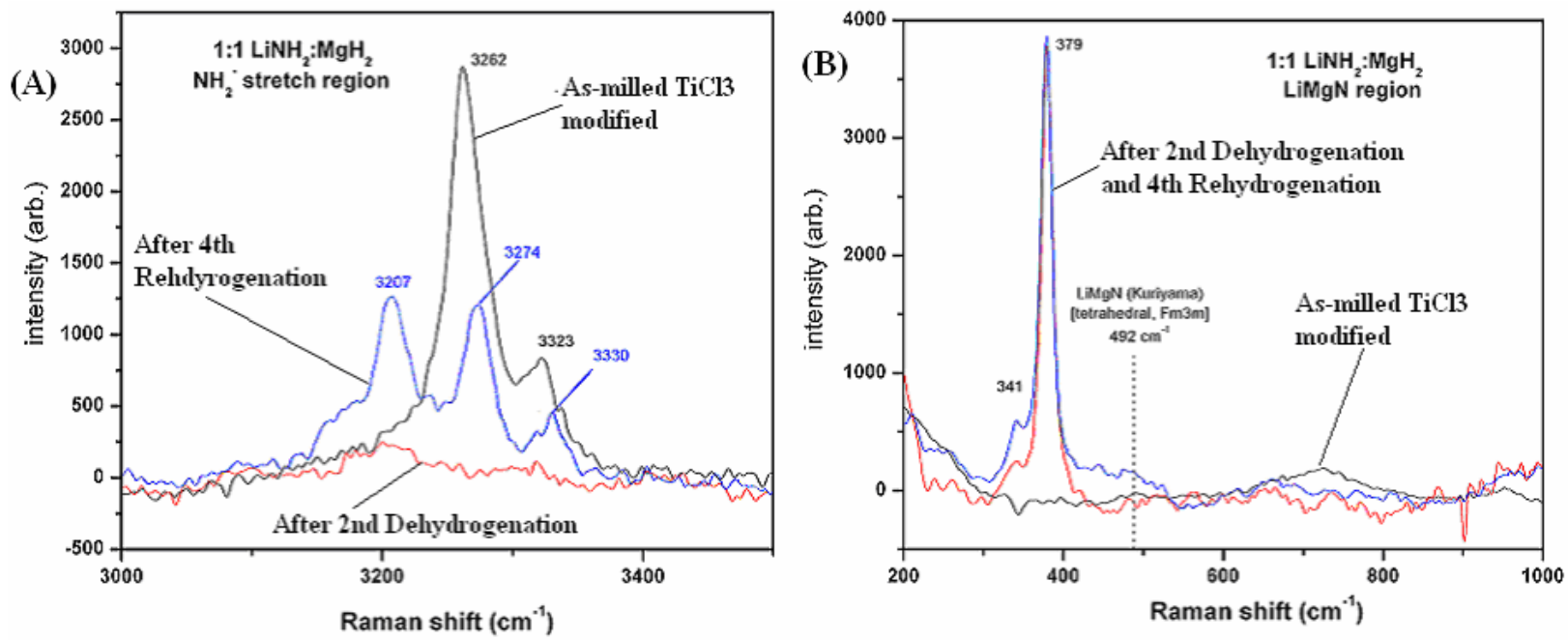

Figure 9. Raman spectra of the as-milled 1:1 $\mathrm{LiNH}_{2}: \mathrm{MgH}_{2}$ with $\mathrm{TiCl}_{3}$ modifier in (A) the high-shift $\mathrm{NH}_{2}^{-}$ region and (B) the LiMgN region. The observed spectrum for the as-milled sample is consistent with highshift stretches for $\mathrm{LiNH}_{2}$. However, the observed LiMgN spectrum for the desorption sample was not consistent with literature [28]. The high-shift $\mathrm{NH}_{2}{ }^{-}$region for the rehydrogenated sample is consistent with the formation of $\mathrm{Mg}\left(\mathrm{NH}_{2}\right)_{2}$ and there is no evidence that $\mathrm{LiNH}_{2}$ has been reformed indicating that the desorption sample did not rehydrogenate to the starting material

It is worth nothing that the spectrum observed doublet closely matches the strongest peaks in the reported spectrum of $\mathrm{Mg}_{3} \mathrm{~N}_{2}$ [29]. The fate of the $\mathrm{Li}$ in the dehydrided sample is less clear. Yamane et al. noted that the insertion of Li into $\mathrm{Mg}_{3} \mathrm{~N}_{2}$ to form $\mathrm{Li}_{0.51} \mathrm{Mg}_{2.49} \mathrm{~N}_{1.83}$ would reduce the space group from Ia3 to I213 [30]. The expected Raman spectrum of such a material could have more peaks, due to the reduction of symmetry, and the frequencies of the strongest peaks could be shifted due to the presence of Li. Neither effect is observed for this material. Additionally, the peaks are sharp, suggesting that there is little disorder in the material as might be expected for the random inclusion of Li. Overall, the Raman spectrum for the dehydrogenated sample does not permit a definitive identification of the dehydrided product or the creation of a new material; however, they are not good enough to rule it out.

The low-shift region of the Raman spectrum for the rehydrogenated sample (seen in Figure 9(A) is essentially identical to the dehydrided sample. The presence of the same doublet that is observed for the dehydrided material suggests that $\mathrm{Mg}_{3} \mathrm{~N}_{2}$ and not $\mathrm{LiMgN}$ was formed during the dehydrogenation process. However, new peaks are observed in the N-H stretching region (Figure 9 (B)). The bands at $3274 \mathrm{~cm}^{-1}$ and 3330 $\mathrm{cm}^{-1}$ are consistent with the formation of $\mathrm{Mg}\left(\mathrm{NH}_{2}\right)_{2}$ [31] and echo the observation of that species in the XRD spectrum. There are no peaks that suggest the reformation of $\mathrm{LiNH}_{2}$ (e.g. consistency with the spectrum of the as-mixed starting materials). As yet unidentified are the peak at $3207 \mathrm{~cm}^{-1}$ and the shoulder at $\sim 3170 \mathrm{~cm}^{-1}$. The other products identified in the XRD spectrum $-\mathrm{MgH}_{2}, \mathrm{LiH}$, and $\mathrm{Mg}_{3} \mathrm{~N}_{2}-$ do not have Raman peaks in this region. Any candidate material(s) would have to be in an amorphous state or otherwise not be observable in the XRD spectrum. For example, the shoulder is coincident with a feature attributed to $\mathrm{Li}_{2} \mathrm{Mg}(\mathrm{NH})_{2}\left(3180 \mathrm{~cm}^{-1}\right)$ [31]. Also, discussion in 
Heyns et al.[29] suggests the possibility that the $3207 \mathrm{~cm}^{-1}$ peak is consistent with the presence of physisorbed $\mathrm{NH}_{3}$, especially if the ammonia has some $\mathrm{NH}_{4}{ }^{+}$character due to a hydrogen bonding interaction between the $\mathrm{N}$ lone pair and bound hydrogen. The observed position is intermediate between the range of " $\mathrm{NH}_{3}$ in amino complexes" (3115$\left.3330 \mathrm{~cm}^{-1}\right)$ and $\mathrm{NH}_{4}^{+}$ion $\left(3040 \mathrm{~cm}^{-1}\right)$. We note that we do not observe an accompanying bending mode expected near $1400-1600 \mathrm{~cm}^{-1}$, but this mode would be less intense and may be unobservable against the large background. On the other hand, the ammonia would not be expected to be observed in XRD spectra. Also, as discussed previously, ammonia release occurs in the modified materials, so the presence of the gas in the sample is reasonable.

\section{Conclusions}

In this paper, we have compared the effect of compositional modifications on the dehydrogenation/rehydrogenation rates, the temperature of initial hydrogen release and the amount of ammonia released from unmodified and modified 1:1 $\mathrm{MgH}_{2}$ and $\mathrm{LiNH}_{2}$. The decomposition steps observed in TGA-RGA data support the 3 step reactions listed in literature; however, further studies are needed to determine decomposition pathway. XRD studies indicate that after discharging at $260^{\circ} \mathrm{C}$ into 1 bar, the resulting mixtures consists of $\mathrm{Mg}_{3} \mathrm{~N}_{2}, \mathrm{LiMgN}$. With the addition of $\mathrm{TiCl}_{3}, \mathrm{VCl}_{3}, \mathrm{NiCl}_{2}$ or $\mathrm{ScCl}_{3}$, the temperature of initial hydrogen release was reduced; however, Ti and $\mathrm{V}$ chlorides also reduced the temperature of ammonia release by promoting a metathesis reaction between $\mathrm{LiNH}_{2}$ and the chlorides. Ni and Sc modified samples showed the highest isothermal absorption capacity followed by unmodified, V and Ti modified samples. After cycling, no discernable kinetic effect remained from the additions. It is concluded that once the metathesis reaction is complete, the added metallic species are no longer active in the sorption cycle. This work has highlighted the requirement of cycling these materials to reach a steady state operating chemistry to evaluate the effectiveness of potential additives as kinetic aids.

\section{References}

[1] Alapati SV, Johnson JK, Sholl DS. Identification of Destabilized Metal Hydrides for Hydrogen Storage Using First Principles Calculations. The Journal of Physical Chemistry B 2006;110:8769.

[2] Lu J, Fang ZZ, Choi YJ, Sohn HY. Potential of Binary Lithium Magnesium Nitride for Hydrogen Storage Applications. The Journal of Physical Chemistry C 2007;111:12129.

[3] Akbarzadeh AR, V. Ozolins, Wolverton C. First-Principles Determination of Multicomponent Hydride Phase Diagrams: Application to the Li-Mg-N-H System. Advanced Materials 2007; 19:3233.

[4] Peles A, Van de Walle CG. Role of charged defects and impurities in kinetics of hydrogen storage materials: A first-principles study. Physical Review B 2007;76:214101.

[5] Majzoub EH, Gross KJ. Titanium-halide catalyst-precursors in sodium aluminum hydrides. Journal of Alloys and Compounds 2003;356-357:363.

[6] Naik M-u-d, Rather S-u, Zacharia R, So CS, Hwang SW, Kim AR, Nahm KS. Comparative study of dehydrogenation of sodium aluminum hydride wet-doped with $\mathrm{ScCl} 3, \mathrm{TiCl} 3, \mathrm{VCl} 3$, and $\mathrm{MnCl} 2$. Journal of Alloys and Compounds 2009;471:L16.

[7] Bogdanovic B, Brand RA, Marjanovic A, Schwickardi M, Tölle J. Metal-doped sodium aluminium hydrides as potential new hydrogen storage materials. Journal of Alloys and Compounds 2000;302:36. 
[8] Bogdanovic B, Felderhoff M, Pommerin A, Schüth F, Spielkamp N, Stark A. Cycling properties of $\mathrm{Sc}$ - and $\mathrm{Ce}$-doped $\mathrm{NaAlH} 4$ hydrogen storage materials prepared by the one-step direct synthesis method. Journal of Alloys and Compounds 2009;471:383.

[9] Wronski ZS, Carpenter GJC, Czujko T, Varin RA. A new nanonickel catalyst for hydrogen storage in solid-state magnesium hydrides. International Journal of Hydrogen Energy 2010; In Press,

Corrected Proof.

[10] Oelerich W, Klassen T, Bormann R. Metal oxides as catalysts for improved hydrogen sorption in nanocrystalline Mg-based materials. Journal of Alloys and Compounds 2001;315:237.

[11] Malka IE, Czujko T, Bystrzycki J. Catalytic effect of halide additives ball milled with magnesium hydride. International Journal of Hydrogen Energy 2010;35:1706.

[12] Liang G, Huot J, Boily S, Van Neste A, Schulz R. Catalytic effect of transition metals on hydrogen sorption in nanocrystalline ball milled $\mathrm{MgH} 2-\mathrm{Tm}(\mathrm{Tm}=\mathrm{Ti}, \mathrm{V}, \mathrm{Mn}, \mathrm{Fe}$ and $\mathrm{Ni}$ ) systems. Journal of Alloys and Compounds 1999;292:247.

[13] Lu J, Choi YJ, Fang ZZ, Sohn HY. Effect of milling intensity on the formation of LiMgN from the dehydrogenation of LiNH2-MgH2 (1:1) mixture. Journal of Power Sources 2010;195:1992.

[14] Wang Q, Chen Y, Niu G, Wu C, Tao M. Nature of Ti Species in the Li-Mg-N-H System for Hydrogen Storage: A Theoretical and Experimental Investigation. Industrial \& Engineering Chemistry Research 2009;48:5250.

[15] Song Y, Guo ZX, Yang R. Influence of titanium on the hydrogen storage characteristics of magnesium hydride: a first principles investigation. Materials Science and Engineering A 2004;365:73.

[16] Chen P, Xiong Z, Luo J, Lin J, Tan KL. Interaction of hydrogen with metal nitrides and imides. Nature 2002;420:302.

[17] Luo W, Stewart K. Characterization of $\mathrm{NH}_{3}$ formation in desorption of Li-Mg-N-H storage system. Journal of Alloys and Compounds 2007;440:357.

[18] Markmaitree T, Osborn W, Shaw LL. Comparisons between $\mathrm{MgH}_{2}$ - and $\mathrm{LiH}$-containing systems for hydrogen storage applications. International Journal of Hydrogen Energy 2008;33:3915.

[19] Hu J, Fichtner M. Formation and Stability of Ternary Imides in the Li-Mg-N-H Hydrogen Storage System. Chemistry of Materials 2009;21:3485.

[20] Hu J, Liu Y, Wu G, Xiong Z, Chen P. Structural and Compositional Changes during Hydrogenation/Dehydrogenation of the $\mathrm{Li}-\mathrm{Mg}-\mathrm{N}-\mathrm{H}$ System. Journal of Physical Chemistry $\mathrm{C}$ 2007;111:18439

[21] Liu Y, Zhong K, Gao M, Wang J, Pan H, Wang Q. Hydrogen Storage in a $\mathrm{LiNH}_{2}-\mathrm{MgH}_{2}(1: 1)$ System. Chemistry of Materials 2008;20:3521.

[22] Liang C, Liu Y, Luo K, Li B, Gao M, Pan H, Wang Q. Reaction Pathways Determined by Mechanical Milling Process for Dehydrogenation/Hydrogenation of the $\mathrm{LiNH}_{2} / \mathrm{MgH}_{2}$ System. Chemistry - A European Journal 2010;16:693.

[23] Tsuda M, Diño WA, Kasai H, Nakanishi H, Aikawa H. Mg-H dissociation of magnesium hydride MgH2 catalyzed by 3d transition metals. Thin Solid Films 2006;509:157.

[24] Lohstroh W, Fichtner M. Reaction steps in the Li-Mg-N-H hydrogen storage system. Journal of Alloys and Compounds 2007;446-447:332.

[25] Osborn W, Markmaitree T, Shaw LL. Evaluation of the hydrogen storage behavior of a $\mathrm{LiNH}_{2}+\mathrm{MgH}_{2}$ system with 1:1 ratio. Journal of Power Sources 2007;172:376.

[26] Sandrock G, Gross K, Thomas G. Effect of Ti-catalyst content on the reversible hydrogen storage properties of the sodium alanates. Journal of Alloys and Compounds 2002;339:299.

[27] Santisteban JR, Cuello GJ, Dawidowski J, Fainstein A, Peretti HA, Ivanov A, Bermejo FJ. Vibrational spectrum of magnesium hydride. Physical Review B 2000;62:37.

[28] Kuriyama K, Yamashita Y, Ishikawa T, Kushida K. Raman scattering from the filled tetrahedral semiconductor LiMgN: Identification of the disordered arrangement between Li and Mg. Physical Review B (Condensed Matter and Materials Physics) 2007;75:233204.

[29] Heyns AM, Prinsloo LC, Range K-J, Stassen M. The Vibrational Spectra and Decomposition of $\alpha$ Calcium Nitride $\left(\alpha-\mathrm{Ca}_{3} \mathrm{~N}_{2}\right)$ and Magnesium Nitride $\left(\mathrm{Mg}_{3} \mathrm{~N}_{2}\right)$. Journal of Solid State Chemistry 1998;137:33.

[30] Yamane H, Okabe TH, Ishiyama O, Waseda $\mathrm{Y}$, Shimada M. Ternary nitrides prepared in the $\mathrm{Li}_{3} \mathrm{~N}-$ $\mathrm{Mg}_{3} \mathrm{~N}_{2}$ system at 900-1000 K. Journal of Alloys and Compounds 2001;319:124. 
[31] Hattrick-Simpers JR, Maslar JE, Niemann MU, Chiu C, Srinivasan SS, Stefanakos EK, Bendersky LA. Raman spectroscopic observation of dehydrogenation in ball-milled $\mathrm{LiNH}_{2}-\mathrm{LiBH}_{4}-\mathrm{MgH}_{2}$ nanoparticles. International Journal of Hydrogen Energy 2010;In Press, Corrected Proof. 